United States Department of the Interior

U.S. Geological Survey

\title{
GEOLOGIC MAP OF THE EASTERN YUKON-TANANA REGION, ALASKA
}

compiled by

Helen L. Foster ${ }^{1}$

OPEN-FILE REPORT 92-313

1992

This report is preliminary and has not been reviewed for conformity with U.S. Geological Survey editorial standards or with the North American Stratigraphic Code. Any use of trade product or firm names is for descriptive purposes only and does not imply endorsement by the U.S. Government.

${ }^{1}$ Menlo Park, CA 94025 


\section{CONTENTS}

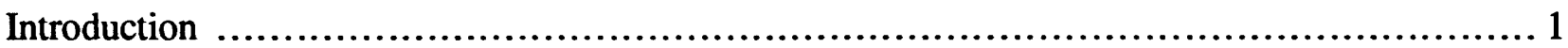

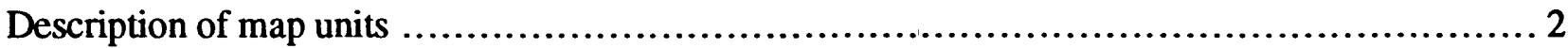

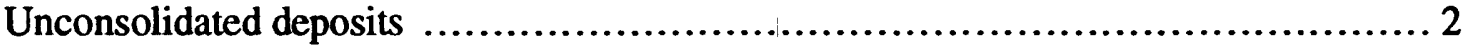

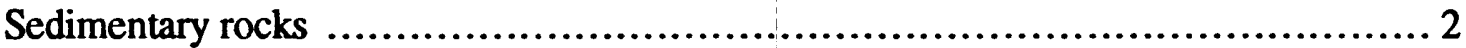

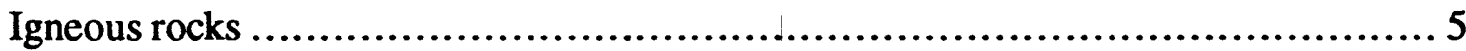

Metamorphic rocks

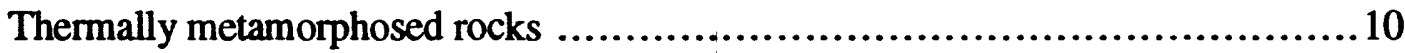

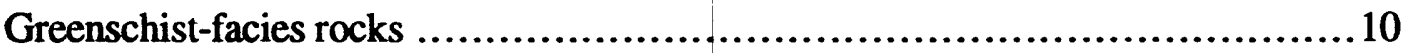

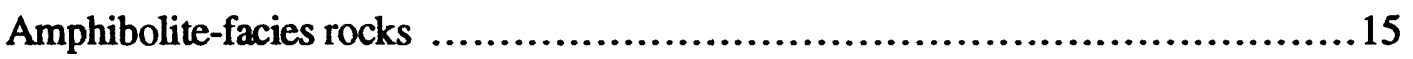

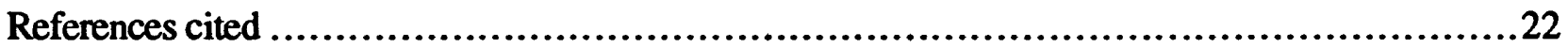




\title{
GEOLOGIC MAP OF THE EASTERN YUKON-TANANA REGION, ALASKA
}

\author{
compiled by
}

Helen L. Foster

\section{INTRODUCTION}

The eastern Yukon-Tanana region is an area of hills and mountains, largely unglaciated, which lies in east-central Alaska between the Tintina fault zone on the north and the Tanana River on the south. This region comprises the largest part of the physiographic division known as the Yukon-Tanana Upland (Wharhaftig, 1965). The rocks of the area are primarily quartzitic, pelitic, calcareous, and mafic metasedimentary rocks with some mafic to felsic meta-igneous rocks, which have been extensively intruded by Mesozoic and Cenozoic granitic rocks and minor amounts of intermediate and mafic rocks. Cretaceous and Tertiary volcanic rocks are abundant in the eastern part of the area. Late Cretaceous and Tertiary nonmarine sedimentary rocks were deposited in small basins, commonly associated with volcanic rocks and (or) faults. Alpine-type ultramafic rocks, along with greenstones, basalts, gabbros, cherts, graywackes, and other sedimentary rocks, crop out in places mostly in the northern part of the area.

Most of the map area is included in the Yukon Crystalline terrane (Tempelman-Kluit, 1976 and Churkin and others, 1982). In the terminology of Jones and others (1984) it makes up the largest part of the Yukon-Tanana terrane. The ultramafic and associated mafic and sedimentary rocks have been included in the Seventymile terrane (Jones and others, 1984 and Foster and others, 1987). Some workers separate some of the amphibolite facies metamorphic rocks (those in the eastern part of the region that give Late Triassic and Early Jurassic metamorphic cooling ages, as opposed to Cretaceous cooling ages; unit $\mathrm{P} 2 \mathrm{bg}$ ), and the Jurassic to Triassic plutons that intrude them (unit J Fg), into another terrane (the Stikinia terrane of Jones and others (1984), the Teslin-Taylor Mountain terrane (Hansen, 1990), or the Taylor Mountain terrane (Dusel-Bacon and Hansen, 1992)). The Yukon-Tanana terrane is generally considered a composite terrane and is commonly divided into subterranes (Churkin and others, 1982; Aleinikoff and others, 1987).

This map (Plate 1) is primarily a compilation of the 1:250,000 scale geologic maps of the Eagle (Foster, 1976), Tanacross (Foster, 1970), Circle (Foster and others, 1983) and Big Delta (Weber and others, 1978) quadrangles. Data are also included on parts of the Livengood (Chapman and others, 1971), Fairbanks (Forbes and Weber, 1982, and Robinson and others, 1990), and Charley River quadrangles (Brabb and Churkin, 1969, and Foster and Keith, 1987). Some minor changes have been made based largely on the author's subsequent field work. The unmetamorphosed and (or) slightly metamorphosed rocks in the Tintina fault zone are not differentiated on this map because they are more closely related stratigraphically to rocks north of the Tintina fault zone and to those to the west than they are to those south of the Tintina fault zone in the map area.

On this map, units are defined primarily on the basis of lithology, degree of metamorphism, and limited age data. Terrane and subterrane relationships that have been suggested for the units are mentioned in the descriptions, but do not define the units. Nearly all of the map units that consist of metamorphic rocks are fault bounded. Poor exposure, because of extensive vegetation cover and surficial deposits, a paucity of fossils and other age control, and complex structural relationships, have deterred the obtaining of adequate data needed for the formal naming and reliable correlation of units.

The faults shown on the map are mostly those shown on previous maps and represent only a very small proportion of the faults present in the area. Several faults, such as the one forming the northwest boundary of the map area and the fault between units $P_{z b g}$ and $P_{z q}$ in the Eagle quadrangle, actually represent fault zones where there are many closely spaced faults. Some faults are shown by dashed lines because, at present, the location, kind, time of formation, or significance is unresolved. For instance, some faults formerly considered as thrust faults are now suspected of being extensional faults (Pavlis and others, 1988), and some contacts shown as faults are considered gradational contacts or unconformities (Weber and others, 1985). The lack of consensus on faulting in the area results in differences in the perception of the order of 
structural stacking of units and the overall interpretation of the structural history of the area (Weber and others, 1985; Foster and others, 1987; Nokleberg and others, 1989; and Hansen and others, 1991).

\section{DESCRIPTION OF MAP UNITS}

\section{UNCONSOLIDATED DEPOSITS} glacial, lacustrine, eolian, landslide, and organic silt and peat deposits. The most extensive and thickest deposits are along the Tanana and Yukon Rivers. Only large areas of Qs are shown on this map. Alluvium consists mostly of gravel, sand, and silt which ranges from poorly- to well-sorted and from unstratified to well-stratified. It includes flood plain and terrace deposits. Organic silt and peat, commonly perennially frozen, fill many old ox bows and other depressions. Colluvium includes boulders, gravel, sand, silt and angular rock fragments found mostly along valley sides of large streams. It is generally poorly sorted and poorly stratified. Glacial deposits are found in many valleys and along valley walls. Morainal and outwash material is common in the Tanana River valley along with small areas of lake deposits or other glacial deposits. Sand dunes and loess deposits, in places ten meters or more thick, are common on the north side of the Tanana River on terraces and in low hills. Unsorted landslide debris, fine to coarse talus, and large to small alluvial fan deposits are present locally. Thin layers of white or light gray volcanic ash, both air fall and reworked, are common a few centimeters to several meters below the surface. Includes material of Pleistocene and Holocene age, but Holocene age material is most abundant.

\section{SEDIMENTARY ROCKS}

SEDIMENTARY ROCKS--Conglomerate, sandstone, tuffaceous sandstone, tuff, shale, and lignitic coal; nonnarine; mapped mostly in the Eagle quadrangle, but there are small deposits associated with volcanic rocks in the eastem Big Delta quadrangle and in the Tintina fault zone in the northwestern Circle quadrangle which are probably of Tertiary age (Weber and Foster, 1982). A few deposits in the eastern Tanacross quadrangle, too small to show on the map, also are most likely Tertiary in age. Conglomerates are fine to very coarse. Clasts range in size from small pebbles to large blocks $0.5 \mathrm{~m}$ across; blocks are angular, sub-angular or rounded. In the northern Eagle quadrangle, most of the conglomerate consists of well-rounded white and tan quartz and black chert clasts 2 to $13 \mathrm{~cm}$ in diameter in a quartzose matrix.

Pebbles of green volcanic rock are sparse. The source of the clasts is unknown, but they may have been derived from terrains to the north or northwest across the Tintina fault. However, in the southern Eagle quadrangle, clasts are dominantly metamorphic rock of local derivation and commonly large and sub-angular. Conglomerate interlayered with sandstone is generally pebble conglomerate. Sandstone and tuffaceous sandstone commonly contain organic material; leaf impressions have been found locally. Shale found near Napoleon Creek (southeastern Eagle quadrangle) is dark gray and well-indurated and breaks into long (up to $15 \mathrm{~cm}$ ) slender fragments. Near Chicken, the sedimentary rocks are mostly conglomerate, sandstone, and tuffaceous sandstone, but also include vertical coal seams, white friable tuff, and dark-gray glassy tuff containing abundant plant fragments (Foster, 1976). Coal contains much amber. 
In the Eagle quadrangle, most of the deposits are Miocene or Pliocene in age, as indicated by fossil pollen and plant remains. In the Chicken area, southeastern Eagle quadrangle, sedimentary rocks of at least two different Tertiary ages occur.

However, some of the deposits in the area near the Tintina fault may be Cretaceous in age.

The sedimentary rocks near Napoleon Creek are mapped in this unit because they are near other Tertiary sedimentary rocks, but no fossil pollen was found in them. The lack of pollen and degree of induration suggest the possibility that these rocks may be Cretaceous in age.

The sedimentary rocks of unit Ts are folded and faulted. For instance, a thick coal bed mined near Chicken was in a vertical position (Mertie, 1937). They are similar in lithology, degree of consolidation, and general appearance to the rocks of unit TKs. The sedimentary rocks of the Yukon-Tanana region appear to have been deposited in small, discontinuous basins, at least some of which resulted from faulting.

On the 1:250,000 geologic map of the Eagle quadrangle (Foster, 1976) unit Ts is represented by units Ts and TKd, in the Big Delta quadrangle (Weber and others, 1978) by unit designation Tcs, and in the Circle quadrangle (Foster and others, 1983) by unit Tcs. In the Tanacross quadrangle (Foster, 1970) a few sedimentary rocks of Tertiary age are included in units $\mathrm{Kr}$ and $\mathrm{Tf}$.

SEDIMENTARY ROCKS--Conglomerate, sandstone, tuffaceous sandstone, tuff, shale, siltstone, and lignitic coal; nonmarine. These rocks are present in the Tanacross and Eagle quadrangles. Conglomerates are fine to coarse; clasts range in size from small pebbles to large blocks 1 meter across; the blocks are generally angular or sub-angular, but some large clasts are rounded. Clasts are dominantly metamorphic rock of local derivation. Some sandstone and tuffaceous sandstone contain organic material and may have leaf impressions. In the northern Tanacross quadrangle south of the West Fork of the Dennison Fork of the South Fork of the Fortymile River thin layers of cherty rock, probably tuff, appear to be interlayered with sandstone and conglomerate. The cherty fragments are red, gray, dark gray, green and greenish gray, and in some rocks the colors are banded; only small fragments, not in outcrop, have been found. Near this locality, well-developed folds and small thrust faults were previously exposed (Foster and Cushing, 1985). Tuff and tuffaceous sediments interlayered with volcanic rocks in the southern Tanacross quadrangle, along the north side of the Tanana River, are reddish and purplish in color.

In the northern Eagle Quadrangle, the deposits are dominantly conglomerate and sandstone with minor lignite and shale beds. The conglomerate clasts are mostly well-rounded quartzite, white quartz, and black chert in a quartzose matrix like those in unit Ts. The clasts are not of local origin and were probably derived from Paleozoic rocks north of the Tintina fault. In places the beds are nearly vertical (Mertie, 1937).

The rocks of unit TKs in the Tanacross quadrangle are mostly Cretaceous in age based on fossil pollen identifications (Foster and Igarashi, 1990), but in places, Tertiary and Cretaceous deposits are present in the same area and the rocks are folded and faulted together. In the northern Eagle quadrangle limited fossil data indicate that probably rocks of both Late Cretaceous and Tertiary age crop out (Mertie, 1937 and Foster, 1976). The Tertiary and Cretaceous sedimentary rocks 
are so similar in lithology, general appearance, and structure that they can only be distinguished by the fossil pollen that some contain.

On the 1:250,000 geologic map of the Tanacross quadrangle (Foster, 1970) unit TKs is shown as unit Kr. On the 1:250,000 geologic map of the Eagle quadrangle (Foster, 1976) unit TKs is shown as unit TKd.

Mza

ARGILLITE--Dark grayish-black; carbonaceous. Unit may include other rock types but is incompletely mapped because of a heavy vegetation cover. Unit is shown only in a small area of the northern Eagle and southern Charley River quadrangles. Age is not known, but the unit may be equivalent to the Glenn Shale (Mesozoic) (Brabb and Churkin, 1969) of the Charley River quadrangle.

SEDIMENTARY AND SLIGHTLY METAMORPHOSED SEDIMENTARY ROCKS--Includes chert, limestone, graywacke, argillite, sandstone, conglomerate, phyllite, quartzite, and tuff. Locally interlayered with greenstone. Chert is green, light and dark gray, red, mottled green and gray; massive, closely fractured with abundant silica veins and veinlets, and commonly has a sugary texture from recrystallization. Limestone is most commonly dark gray or black but may be light gray; mostly thin-layered, but locally massive; partly or wholly recrystallized in most places. Graywacke, sandstone, conglomerate, argillite, and tuffaceous rocks are generally slightly metamorphosed and commonly are found as rubble near greenstone exposures.

Fossils indicate that these rocks range from at least as old as Mississippian to as young as Late Triassic. Mississippian radiolarians are present in red and gray chert on the north side of Mt. Sorenson in the Eagle and Charley River quadrangles (D.L. Jones, written commun., 1984 in Foster and others, 1987) and Mississippian conodonts are found in marble on the South Fork of the Fortymile River in the southeast Eagle quadrangle (G.W. Cushing, oral commun., 1985). Red chert in the Salcha River area of the Big Delta quadrangle contains radiolarians and conodonts of Early Permian age (Weber and others, 1978). Quartzite near the Seventymile River in the northern Eagle quadrangle contains brachiopods of Permian age (Foster, 1976) and a carbonaceous limestone in the east central Eagle quadrangle contains Late Triassic conodonts (T.R. Carr, written commun., 1985 in Foster and others, 1987).

The rocks of this unit are considered part of the Seventymile terrane (Foster and others, 1987) and were included in geologic map unit sp. On the Eagle 1:250,000 geologic map (Foster, 1976) they were shown as unit Pq and on the Big Delta 1:250,000 geologic map (Weber and others, 1978) they were part of units Pgc and Pzq.

UNDIFFERENTIATED SEDIMENTARY AND (OR) SLIGHTLY

METAMORPHOSED SEDIMENTARY AND IGNEOUS ROCKS--Includes limited exposures of at least four different formations within the Tintina fault zone: chert and argillite; limestone and chert; maroon and green argillite with minor interlayered greenstone, grit, and quartzite; and limestone associated with basalt. These rocks appear to have affinities to rocks in the Livengood quadrangle and to areas north of the Tintina fault zone in Alaska and Canada. They are probably mostly Paleozoic in age, but may include some rocks as old as Proterozoic. The rocks of this unit are mapped as units $P_{z C}, P_{z l}, P_{z p} \in a$, and $P_{z p} C_{b}$ on the 1:250,000 scale geologic map of the Circle quadrangle (Foster and others, 1983). 


\section{IGNEOUS ROCKS}

Qp

$\mathrm{Tt}$

$\mathrm{TKg}$

TKp
BASALT OF PRINDLE VOLCANO-Alkali-olivine basalt, dark gray to black or brownish-gray; vesicular; contains abundant green peridotite and light gray granulite inclusions. Prindle Volcano, eastern Tanacross quadrangle, is a cone 230 to $265 \mathrm{~m}$ high with a $100 \mathrm{~m}$ deep crater. A lava flow extends about $6.4 \mathrm{~km}$ downslope from the breached crater. The basalt consists of clinopyroxene, olivine, and opaque minerals in a fine-grained groundmass believed to contain occult nepheline and potassium feldspar. The peridotite inclusions range in size from xenocrysts to polycrystalline masses up to $15 \mathrm{~cm}$ in diameter. Mineral assemblages include olivine, orthopyroxene, clinopyroxene, and spinel in at least 5 different combinations. The mineral assemblages of granulite inclusions are characterized by hypersthene and (or) clinopyroxene and plagioclase (Foster and others, 1966). Indirect evidence suggests that Prindle Volcano is post-early Pleistocene in age but older than 1,900 years B.P. (Foster, 1981).

WELDED TUFF AND OTHER FELSIC VOLCANIC ROCKS--Includes tuff, welded tuff, volcanic breccia, lava, and shallow intrusive rocks. White, gray, pink, light brown, or orange brown are the most common rock colors, but glassy rocks can be dark gray or green. Welded tuff commonly has embayed quartz crystals. Most welded tuff is probably remnants of caldera-fill deposits. Xenoliths are present locally. In some places, tuff and breccia contain fragments of quartzite, greenstone, and schist. Most rocks are highly altered and iron sulfides are common. These rocks are mostly Tertiary in age on the basis of K/Ar determinations (Foster and others, 1987), but the unit may include some Cretaceous rocks. This unit is mapped as Tf in the Tanacross (Foster, 1970) and Big Delta (Weber and others, 1978) quadrangles and as units $\mathrm{Tf}$ and $\mathrm{Tw}$ in the Eagle quadrangle (Foster, 1976).

GRANITE-Also includes the hornblende-augite-biotite diorite through hornblendeaugite-syenite to hornblende-biotite-quartz monzonite of Mt. Fairplay in the Tanacross quadrangle. The granitic rocks of this unit have ages which range from about 70 to $50 \mathrm{Ma}$ (Foster and others, 1987), but most were intruded in the Early Tertiary. A few granitic rocks, including those of two plutons in the northwest Circle quadrangle, are very latest Cretaceous in age or around the time of the Tertiary-Cretaceous boundary (DuBois and others, 1986). Granite of the Circle and Big Delta quadrangles is mostly biotite granite, but includes some with hornblende or muscovite. Tourmaline is a common accessory mineral. Grain size ranges from fine to coarse, but medium to coarse grained rock textures predominate. Porphyritic textures are fairly common. The rocks are generally considerably weathered and crumble easily. Many plutons show at least three phases as indicated by such factors as grain size and mafic-mineral content. They are quartz-rich and corondum normative. Most of the plutons are small, $3 \mathrm{~km}^{2}$ or less. Tors are common. Plutons of this unit are found mostly in the Circle quadrangle or northern Big Delta quadrangle. The Mount Fairplay pluton in the Tanacross quadrangle is an exception. Rocks of plutons that have not been radiometrically dated, but which are presumed to be this age, are indicated by a query following the map designation. Foster and others (1987) show these rocks as Tg. They are shown by the symbol Ts (Mount Fairplay pluton) on the Tanacross 1:250,000 geologic map (Foster, 1970), included in unit TMzg on the Eagle 1:250,000 map (Foster, 1976), represented by unit $\mathrm{Tg}$ on the Big Delta 1:250,000 map (Weber and others, 1978) and included in unit TKg on the Circle 1:250,000 map (Foster and others, 1983).

GRANITE PORPHYRY--Pink or gray; generally has well-terminated quartz crystals 0.5 to $2 \mathrm{~cm}$ long. Groundmass composed primarily of quartz, potassium feldspar, 
and plagioclase; ranges from fine to fairly coarse grained. Locally rocks of porphyritic texture grade into fine-grained equigranular rocks of similar composition. Dikes and small bodies intrude the metamorphic rocks and some granitic rocks of the eastern Yukon-Tanana region. The rocks of this unit are not dated isotopically, but geologic relationships indicate a probable Tertiary or Late Cretaceous age. Occurrences large enough to be shown on Plate 1 are known only in the Tanacross quadrangle. On the Tanacross 1:250,000 geologic map (Foster, 1970), this unit is designated Tp.

MAFIC AND INTERMEDIATE VOLCANIC ROCKS--Present in flows, small intrusions, dikes and breccias; dark gray to black, brownish gray, dark maroon, and greenish gray; mostly andesitic to basaltic in composition; uniformly fine grained to coarsely porphyritic. Some lava is vesicular and amygdaloidal. Phenocrysts are plagioclase, biotite, amphibole, and pyroxene. Iron sulfides are abundant. Locally much altered. Breccias include many fragments of schist and rarely of granite. Poorly dated, but probably includes rocks of both Tertiary and Cretaceous age. These rocks are included in unit Tm on the 1:250,000 geologic map of the Tanacross quadrangle (Foster, 1970)

DIORITE--Includes some quartz diorite, diorite porphyry, granodiorite, and gabbro. Mostly medium to dark gray and medium and fine grained; generally massive. Dominantly pyroxene diorite in the Big Delta quadrangle with biotite and plagioclase generally present but amphibole may be absent. Commonly, especially in the Eagle quadrangle, a marginal facies of granitic plutons (mostly not differentiated on this map). Most of the diorite in unit TMzd is believed to be Cretaceous in age on the basis of three $\mathrm{K} / \mathrm{Ar}$ age determinations on diorite in the Big Delta quadrangle (Wilson and others, 1985) and because much diorite in the Eagle quadrangle is associated with Cretaceous granitic rocks. However, some undated rocks in this unit could be earlier Mesozoic or Tertiary in age. On the Eagle 1:250,000 geologic map (Foster, 1976) some diorite of this unit is shown as unit TMzd. On the Big Delta 1:250,000 geologic map (Weber and others, 1978), diorite is shown as unit Kd.

TMzb BASALT AND GABBRO-Includes basaltic ejecta and basaltic volcanic breccia; on the northeast margin of Mosquito Flats in the central Tanacross quadrangle may include lava and breccias, conglomerates, and rocks of mudflow origin, some of which are andesitic. Rocks are dark gray to black and dark greenish gray. Olivine abundant in many. Commonly massive; locally vesicular. Near Chicken, in the southern Eagle quadrangle, and north of Tok, on the north side of the Tanana River in the Tanacross quadrangle, some of the rocks are coarse grained and range from gabbro to basalt. The basalt north of Tok is probably Late Cretaceous; however, locally basalt may be younger because some topographic features suggestive of volcanic cones and lava flows remain. Some of the mafic rocks in the Chicken area are no older than Tertiary because basalt dikes cut Tertiary sedimentary rocks in at least two places. This unit was shown as QTb, and Tgb on the Tanacross 1:250,000 map (Foster, 1970) and as Tb on the Eagle 1:250,000 map (Foster, 1976).

GRANITE AND GRANODIORITE--Locally includes quartz monzonite, diorite, aplite, alaskite, and pegmatite; light gray to light pinkish gray, fine to coarse grained; equigranular to coarsely porphyritic, but generally medium grained. Biotite is the most abundant mafic mineral, but many rocks contain both biotite and hornblende; some have only hornblende. Alteration of feldspars is generally slight to moderate and biotite is commonly partly chloritized. Xenoliths and roof pendants of 
metamorphic rocks are present locally. $\mathrm{K} / \mathrm{Ar}$ age determinations give age ranges from about 110 to $85 \mathrm{Ma}$. Most are 95-90 Ma (Foster and others, 1987). The unit may include minor Tertiary age intrusive rocks as dikes and small bodies, particularly in the southwest part of the Eagle quadrangle. Undated rocks that are probably of this age are indicated by a query on the map. Bodies range in size from less than $1 \mathrm{~km}^{2}$ to plutons of batholithic proportions. In the southeast comer of the Tanacross quadrangle, poorly exposed coarse- to fine-grained igneous rocks of fairly felsic to fairly mafic composition are tentatively included in unit $\mathrm{Kg}$ ? Generally, they are more altered and more weathered than most rocks included in this unit and may be older than Cretaceous. They were mapped as unit Mzmu on the 1:250,000 scale geologic map of the Tanacross quadrangle (Foster, 1970).

The granitic rocks of this unit $(\mathrm{Kg})$ are also shown as $\mathrm{Kg}$ by Foster and others (1987). They are shown on the Tanacross 1:250,000 scale geologic map as Mzg (Foster, 1970) on the Eagle 1:250,000 scale geologic map as TMzg (Foster, 1976) on the Big Delta 1:250,000 scale geologic map as $\mathrm{Kg}$, (Weber and others, 1978), and on the Circle 1:250,000 scale geologic map as TKg (Foster and others, 1983).

WELDED TUFF AND OTHER FELSIC VOLCANIC ROCKS--Includes tuff, lava, tuff breccia, pumice, pumice breccia, volcanic conglomerate, pitchstone, and tuffaceous sediments. Flows, hypabyssal intrusions, and dikes are recognized in places. Tuff is light gray or light-pink, fine to coarse grained and includes lapilli tuff with concretionary lapilli. Lava is white, light-gray, light green, light pink, redbrown, tan, purple, or cream-colored; aphanitic to porphyritic. Xenoliths of metamorphic and volcanic rocks are abundant. Welded tuff is common, especially in the Sixtymile Butte area of the Tanacross quadrangle, and is believed to be caldera-fill deposits (Bacon and others, 1990). Breccia includes some fragments of gneiss, schist, quartzite, and rare granitic rocks. Flow structures are clearly evident in many places. Quartz phenocrysts are commonly abundant and are generally wellterminated crystals of smoky quartz. Iron sulfides are widely distributed. Most of the rocks are considerably altered. Rocks in this unit are mostly Cretaceous in age, as indicated by K/Ar determinations, but some may be Tertiary (Bacon and others, 1990). Dikes and small bodies of the types of rock in this unit too small to be shown on this map, are present throughout the eastern Yukon-Tanana region.

Rocks of this unit are included in unit Tf on the 1:250,000 geologic map of the Tanacross quadrangle (Foster, 1970).

GRANITE AND GRANODIORITE--Includes homblende plagioclase porphyry, minor quartz monzodiorite, and diorite. The largest occurrence is the $648 \mathrm{~km}^{2}$ batholith, Taylor Mountain, in the southern Eagle and northern Tanacross quadrangles. The batholith is composed mostly of medium-grained equigranular granite, but locally it is granodiorite to diorite. Plagioclase (oligoclase to andesine), sericitized potassium feldspar, quartz, hornblende, and biotite are the major constituents; common accessory minerals are sphene, apatite, and opaque minerals. Plagioclase is generally zoned and sericitized. Quartz is strained and the margins of some grains are granulated. Some biotite has altered to chlorite. The country rock along the northeastern contact with the batholith has been altered by the intrusion; epidote and dikes and sills are abundant. In places along the southern and eastern margins, the texture is slightly gneissic. Radiometric dating indicates that the batholith was intruded in latest Triassic time (Foster and others, 1987).

Hornblende plagioclase porphyry is a characteristic intrusive rock in the vicinity of Mt. Veta in the southwestern Eagle and northwestern Tanacross quadrangles.

Quartz monzodiorite is a common mineralogy, but more felsic compositions also are 
present. In some very coarse grained porphyritic phases, a mineral alignment defines a weak foliation. These rocks have an integrated plateau age of $188 \pm 2 \mathrm{Ma}$ by the ${ }^{40} \mathrm{Ar} /{ }^{39} \mathrm{Ar}$ method (Cushing, written commun., 1984). A few other hornblende-bearing granitic plutons in the eastern and central Eagle quadrangle are of latest Triassic to Early Jurassic age and others nearby have not yet been dated but may be of similar age. The undated plutons have a query following the map unit designation.

Latest Triassic to Early Jurassic granitic plutons are known only in the $\mathrm{Y}_{4}$ subterrane of Foster and others (1987), the Taylor Mountain subterrane of Dusel-Bacon and Hansen (1991). Some authors have included these plutons in the Stikinia terrane (Jones and others, 1984). Tempelman-Kluit (1979) correlates these rocks with the Klotassin suite in the Yukon Territory and Wheeler and others (1987) includes them in the Quesnel terrane. This unit is indicated by J Fg on the Tanacross and Eagle 1:250,000 geologic maps (Foster 1970 and 1976). Several plutons in the Eagle quadrangle are now included in this unit which were previously included in the unit TMzg of the Eagle 1:250,000 geologic map (Foster, 1976).

MzPzmu GABBRO, SOME ASSOCIATED BASALT AND ANDESITE (?), MINOR DIORITE AND DIABASE, AND UNDIFFERENTIATED MAFIC- AND INTERMEDIATE-COMPOSITION IGNEOUS ROCKS. Generally dark greenishblack or dark gray or dark greenish-gray. Commonly olivine bearing. In the Ketchumstuk area of the northern Tanacross and southern Eagle quadrangles, the rocks are generally much altered with abundant epidote and locally abundant sulfides; may include metagabbro and metabasalt. Gabbroic rocks in the Eagle B-1 quadrangle near the Canadian border and small intrusions near Tetlin Junction are less altered. Columnar jointing is present locally. Mafic dikes (not shown on map) are abundant in many areas. Age of the gabbroic rocks is unknown, but their intrusive relationship to the metamorphic rocks, degree of alteration, and lack of foliation suggests a Mesozoic, probably Cretaceous, age.

These rocks are shown as Tgb (near Tetlin) and Mzgb on the Tanacross 1:250,000 map (Foster, 1970) and as TMzm and MzPzg on the Eagle 1:250,000 map (Foster, 1976).

MzPzb " BASALT AND GABBRO--Mostly fine-grained basaltic rocks that are probably tholeiitic. Includes pillow basalt, gabbro, diabase, mafic tuff, and breccia. Locally has a cataclastic texture. Commonly metamorphosed to prehnite-pumpellyite facies. Considered part of the Mt. Sorenson ophiolite. Mapped in the northern Eagle quadrangle; a little extends into the southern Charley River quadrangle. Age is uncertain but may be late Paleozoic and early Mesozoic. Included in the Seventymile terrane (Foster and others, 1987) and shown as unit MzPzb on the Eagle 1:250,000 geologic map (Foster, 1976).

MzPzt SILICIFIED TUFF--White, light tan or light-gray silica rock. Massive; structureless. Probably of tuffaceous origin. Age unknown. Known to be present only in one area in the northeastern Eagle quadrangle. Mapped as MzPzt on the Eagle 1:250,000 map (Foster, 1976).

Pzgr GREENSTONE WITH TUFF AND SILICA-CARBONATE LENSES--Massive greenstone bodies, originally mostly basaltic pillow lavas and mafic lava flows; generally associated with peridotite bodies. Greenstone is gray-green to dark greenish-black in color and is composed mainly of chlorite, actinolite (or other amphibole), epidote, feldspar, magnetite, quartz, and calcite. Some amphibole is 
bluish-green. Other minerals such as zoisite, sphene, hematite, and other opaque minerals including pyrite, may be present. In places, the greenstone contains amygdules (generally filled with calcite) and pillows. Locally tuff and silicified tuff, commonly red, gray, or green, are interlayered. White and orange-brown silica carbonate lenses crop out particularly in the northem Big Delta quadrangle. The rocks are mostly unmetamorphosed to slightly metamorphosed; some are hydrothermally altered; locally, they may be metamorphosed to greenschist facies. In the northern Eagle quadrangle, the unit includes gabbro and basalt that are comparatively unaltered. At one locality in the northem Eagle quadrangle greenstone is associated with a massive rock containing glaucophane, epidote, and sphene which formed from basaltic lava under blueschist metamorphic conditions (Foster and Keith, 1974). In the Chicken area, the greenstone is believed to have been affected in Early Jurassic time by either late stages of the regional metamorphic event that started before the intrusion of Taylor Mountain, or the intrusion itself. Generally, no foliation or other structures are observed in the greenstone.

The age of the greenstone protoliths is probably Paleozoic based on the ages of fossils found in sedimentary rocks interlayered or closely associated with some greenstones. The glaucophane-bearing rock associated with greenstone in the northern Eagle quadrangle has an upper Permian metamorphic age as indicated by a ${ }^{40} \mathrm{Ar} /{ }^{39} \mathrm{Ar}$ determination (Grant Cushing, oral commun., 1991).

The rocks of this unit are part of the suite of rocks associated with the Seventymile terrane included in unit Sp on the geologic map of Foster and others, 1987. They are shown on the Eagle 1:250,000 geologic map (Foster, 1976) as unit $\mathbf{Z z g}_{2}$ and on the Big Delta 1:250,000 geologic map (Weber and others, 1978) as unit Pgc.

PERIDOTITE, MOSTLY SERPENTINIZED--Generally dark gray to black or greenish-black or brown; commonly weathers to brown, gray, or greenish-gray colors; massive. Peridotite forms a discontinuous belt of alpine-type ultramafic rocks and composes 4 large bodies (the peridotites of Boundary in the southeastern Eagle quadrangle, American Creek in the northeastern Eagle quadrangle, Mount Sorenson in the northwest Eagle quadrangle, and the Salcha River ("Nail" allochthon of Southworth, 1984) in the Big Delta quadrangle, and numerous sporadically distributed small lenses of serpentinite that crop out south of the main belt of ultramafic rocks. The peridotite of Mount Sorenson has previously been described as part of a dismembered ophiolite (Foster and Keith, 1974; Keith and others, 1981). The rocks are mainly partly serpentinized harzburgite and dunite with minor amounts of clinopyroxenite. Chromite is present locally, but is not abundant. Secondary magnetite is common. Tectonic inclusions of rodingite are found in the large peridotite bodies. Silica-carbonate zones are well-developed at the base of the large peridotite body in the Big Delta quadrangle. Commercial quantities of asbestos have been discovered near Slate Creek in the Eagle quadrangle (Mullins and others, 1984).

The large peridotite bodies do not show internal textural effects from regional metamorphism. However, some of the small ultramafic bodies locally have foliation and low-grade metamorphic mineral assemblages where they have been tectonically placed against rocks of other units. However, thrusting and possibly low-grade regional metamorphism has had some effect on the rocks, as indicated by crosscutting veinlets of serpentine, magnetite, chlorite, actinolite, anthophyllite, and magnesite. The ultramafic bodies are generally without foliation or other easily detectable structures, but locally they are highly fractured. Most of the bodies are fault-bounded and appear to have been thrust onto the underlying metamorphic rocks. 
There is little information on the age of the ultramafic rocks. However, on the basis of associated sedimentary and volcanic rocks, they are assumed to have been derived from the mantle and emplaced into oceanic crust in Paleozoic time. They were later thrust onto metamorphic rocks.

These ultramafic rocks are part of the Seventymile terrane of Foster and others (1987), and are included in unit Sp on the map. On the Tanacross 1:250,000 geologic map (Foster, 1970), the peridotite is included in unit MzPzu. On the Eagle quadrangle 1:250,000 geologic map (Foster, 1976), it is included in units MzPzS and MzPzsp. On the Big Delta geologic map 1:250,000 geologic map (Weber and others, 1978), it comprises unit $\mathrm{Pu}$, and on the Circle 1:250,000 geologic map (Foster and others, 1983), it is unit Pzp.

\section{METAMORPHIC ROCKS}

\section{Thermally Metamorphosed Rocks}

HORNFELS--Andalusite-sillimanite and andalusite-mica hornfels, sheared; also cordierite-mica, calc-silicate, calcareous, and cordierite-potassium feldspar-mica hornfels. Includes some gneiss and schist slightly retrograded by contact metamorphism, and some greenschist-facies rocks that have been altered to different degrees by contact metamorphism. Rocks are dominantly metamorphosed to the hornblende-hornfels facies, but some are epidote-hornfels facies. This unit is mapped only in the Eagle quadrangle; other locally hornfelsed and contact metamorphic rocks are included in some of the other metamorphic rock units. The protoliths of the hornfelsed rocks have not been dated isotopically, but geologic relations suggest that they are of Paleozoic age. Most of these rocks were probably initially regionally metamorphosed during the early Mesozoic, but later, they were strongly affected by either Cretaceous or Tertiary thermal metamorphism associated with the intrusion of granitic plutons. This unit is also shown as P $2 h$ on Foster's (1976) 1:250,000 geologic map of the Eagle quadrangle.

\section{Greenschist-Facies Rocks}

QUARTZ-CHLORITE-WHITE MICA SCHIST--Schist is commonly calcareous and is interlayered with quartzite, phyllite, and mafic to felsic metavolcanic rocks. Commonly light green or light greenish-gray in color. In the Tanacross quadrangle, small amounts of biotite are present locally. Some schist has scattered coarse grains of gray, bluish-gray, and glassy quartz. Some quartz grains are single crystals; others are polycrystalline. Large feldspar grains are present in some schist. Carbonate is present interstially, as well as in very thin layers to layers a meter or more thick. The carbonate ranges from finely to coarsely crystalline. Mylonite and partly recrystallized mylonitic textures are common. Foliation is generally welldeveloped. In the southeastern part of the Eagle quadrangle, a strong lineation trending and plunging westerly is formed by small, tight, isoclinal folds. Early formed structures of this unit have been affected by a late open folding. These rocks are all regionally metamorphosed in the greenschist facies. Rocks of unit PzqC extend eastward into Canada and were included in Green's (1972) unit B and were termed the Klondike Schist by McConnell (1905). The age of the protoliths of unit PzqC are unknown, but geological relations indicate that they are probably Paleozoic in age. Mortensen and Sullivan (1991) have obtained mid-Permian U-Pb zircon ages from metavolcanic rocks of the Klondike Schist from the Yukon Territory. The 
time of regional metamorphism is also uncertain but could have been as early as late Paleozoic, although a Late Triassic to Early Jurassic age is suggested by isotopic data determined for the Klondike Schist in the Yukon Territory (Tempelman-Kluit and Wanless,1980; Metcalfe and Clark, 1983).

Rocks of unit $P_{2 q C}$ are unit ws in subterrane $Y_{3}$ of Foster and others (1987). They are included in unit $P_{z q}$ on Foster's (1976) geologic map of the Eagle quadrangle.

MYLONITIC SCHIST AND GNEISS, SEMISCHIST, AND GREENSCHIST-Also includes quartz-white mica chlorite \pm epidote schist, quartz-sericite schist, quartzite, phyllite, marble, metavolcanic rocks including metatuff, metadiorite, and greenstone. The southwestern part of the unit is the most mylonitic and is shown by the symbol " $\Delta$ "; the rocks are mostly mylonite schist and mylonite gneiss with fluxion structure common, and much neomineralization and other recrystallization. Generally the rocks of unit $\mathrm{B}_{2 \mathrm{~ms}}$ are very quartzitic and feldspathic with minor amounts of micas, amphiboles, and epidote-group minerals. Augen gneiss with perthitic microcline augen is common. The northern and eastern parts of this unit are less mylonitic, although mylonite zones are present locally. Semischist is interlayered with quartz-mica-chlorite \pm epidote schist, quartz-sericite schist, phyllite, marble, and, locally, with weakly-foliated greenstone and other metavolcanic rocks. Greenish gray or gray, fine- to coarse-grained, sheared grit or semischist with clear, gray, or bluish-gray grains of quartz (1 to $5 \mathrm{~mm}$ in diameter) are characteristic. Large feldspar grains, mostly microcline, are commonly present. Foliation is generally well developed and has been folded at least once. The rocks of this unit are regionally metamorphosed in the greenschist facies. The age of the protoliths of these rocks is unknown, but geologic relations suggest that they are probably Paleozoic in age, most likely upper Paleozoic. Time of regional metamorphism could have been from late Paleozoic through Mesozoic time. Correlation of these rocks to the Totatlanika Schist, (of probable Late Devonian to Mississippian protolith age), northern Alaska Range, has been suggested (Gilbert and Bundtzen, 1979). Unit Pzms may correlate with unit $P_{2 g s}$ in the northeast part of the area of this map, but no fossils have been found in unit Pzms.

Mertie (1937) included most of these rocks in unit $\mathrm{pO}$, undifferentiated pre-Middle Ordovician. Weber and others (1978) on the 1:250,000 scale geologic map of the Big Delta quadrangle, mapped the mylonitic part of this unit as $P_{2 C}$ and the remaining part of it as unit Pzsg. Foster and others (1987) map these rocks in unit ms of subterrane $Y_{3}$. Nokleberg and others (1989) include these rocks in the Butte subterrane.

Pzgs GREENSCHIST, CALCAREOUS GREENSCHIST, AND QUARTZ-CHLORITEWHITE MICA SCHIST--Also includes marble, greenstone, and quartzite. Greenschist is generally light green or light greenish-gray; commonly calcareous or interlayered with calcareous schist and quartz-chlorite-white mica schist. Some schists are quartzitic and(or) feldspathic with large quartz (or) feldspar grains in a finer grained schistose matrix. Differs from other greenschist-facies units in having abundant layers and lenses of light gray, medium to coarsely crystalline, thin layered to massive marble, that is locally fossiliferous and, in places, $100 \mathrm{~m}$ or more in thickness. Greenstone is grayish-green, dark green, and greenish black; found primarily as dikes, but there may be some interlayered flows. It is composed mainly of chlorite, actinolite, epidote, feldspar, magnetite, quartz, and calcite. Quartzite is tan or gray including dark gray to black quartzite with dark gray graphitic schist layers and partings. Some quartzites have large blue or bluish-gray grains of quartz in a finer-grained matrix. Mylonitic to cataclastic textures are common. The rocks of this unit are mostly regionally metamorphosed to greenschist facies. Locally, 
they are hornfelsed. Biotite is uncommon, and is found mostly in areas having contact metamorphic effects. Garnet is rare. The rocks of this unit are commonly highly sheared, much fractured, and locally brecciated. A northwesterly striking foliation is common. A strong, closely spaced $(10+\mathrm{cm}$ apart $)$ fold-axis lineation is locally conspicuous, especially in the more quartzose rocks. Small faults with prominent gouge and brecciated zones are common.

Protoliths of this unit are of Paleozoic age as indicated by fossils. Paleozoic echinodermal fragments have been found in marble at several localities and conodonts from marble in the northeastern Eagle quadrangle are Mississippian in age (Grant Cushing, oral commun., 1987). The time of major regional metamorphism is uncertain, but could have occurred in the Late Paleozoic or in Mesozoic time. The rocks of this unit may correlate with rocks to the west (unit Pzms) from which they are separated by granitic intrusions. However, no fossils have been found in the rocks of unit Pzms and their age is uncertain. The correlation of these rocks with those of the Yukon Territory is unknown. They may correlate with part of Green's (1972) unit 13 and (or) unit A. They appear to be the same age as Mortensen and Sullivan's Nasina metasedimentary assemblage (1991), but geologic relations are not clear.

Mertie (1937) included the rocks of unit $P_{2} g s$ in unit D, undifferentiated Devonian. In Foster and others (1987) the rocks of unit $P_{\mathbf{z}}$ gs are included in unit gs of subterrane $\mathrm{Y}_{3}$. They may be part of the Butte subterrane of Nokleberg and others (1989). In the Eagle quadrangle, Foster (1976) included unit $P_{2 g}$ in unit $P_{2} q$.

QUARTZITE--Light gray to black. Includes minor gray phyllite, phyllitic and carbonaceous quartz schist, quartz-mica schist, and, locally, layers of graphitic schist. Grain size ranges from very fine to medium, and quartz grains are almost always highly strained. Outcrops are massive to schistose, depending upon the relative amounts of mica and quartz. The rocks of unit $P_{z q}$ generally have welldeveloped foliation which has a regional east-west strike. Shallowly plunging folds, commonly isoclinal, deform foliation and their axes commonly trend a little north of west. An open folding is superimposed on the earlier folding. Along the Taylor Highway in the east-central Eagle quadrangle unit $P_{z q}$ is separated from unit $P_{2 b g}$ by a south-dipping fault zone (Foster and others, 1985).

The rocks of unit $P_{z q}$ range from lower to upper greenschist facies grade. Geologic relationships suggest that the unit is probably Paleozoic in age, but no fossils have yet been found. U-Pb zircon ages on metatuffs interlayered with rocks in the Yukon Territory which are probably an extension of this unit, indicate a Mississippian age for these rocks (Mortensen and Sullivan, 1991). The unit extends eastward from the Eagle quadrangle into the Yukon Territory and is part of Green's (1972) unit A and the Nasina Series of McConnell (1905).

Unit $P_{2 q}$ is shown as unit qs in subterrane $Y_{3}$ in Foster and others (1987). On Foster's 1,250,000 Eagle geologic quadrangle map (1976) unit $P_{2 q}$ comprises the southern part of a unit also called $P_{z q}$. Quartzite is most commonly light to dark gray or black, but includes some tan, maroon, and white quartzite; the dark color is generally due to included carbonaceous material; color changes are present locally because of contact metamorphism. Quartzite is mostly medium grained and thinly layered to massive; commonly contains minor white mica and may be calcareous. Quartzite is 
interlayered with black or dark-gray meta-argillite; may be slaty in places. Gray and tan phyllite, white, moderately to coarsely crystalline marble, and tan and maroon quartzite more commonly crop out in the upper part of the formation, but are absent in places due either to faulting or an unconformity; generally, there are thin layers of white quartz grains parallel to layering, as well as abundant white quartz veins, veinlets, and lenses, some of which cut across foliation and layering. Small isoclinal folds locally deform layering.

In the Circle quadrangle, vitrinite reflectance studies indicate that many of these rocks were subjected to temperatures no higher than $180^{\circ} \pm 50^{\circ} \mathrm{C}$ (Laird and others, 1984), but in the Big Delta quadrangle, some of these rocks appear to be metamorphosed as high as greenschist facies, although no temperature studies have been made as yet. In places in the Big Delta quadrangle, the rocks have been metamorphically upgraded by contact metamorphism.

No fossils have been found in these rocks. Geologic relations suggest that they are probably lower Paleozoic in age and that they stratigraphically overlie the calcareous phyllite of unit P 2 Cp; other contacts are believed to be faults. These rocks may be the stratigraphic equivalent of unit $P_{2 q}$ in the Eagle quadrangle and (or) the Keevy Peak Formation in the Alaska Range (Weber and others, 1978). This unit is included in unit $c p$ of the $Y_{3}$ subterrane in Foster and others (1987). On the 1:250,00 geologic maps of the Big Delta and Circle quadrangles it is shown as unit Pzq. It is included in the Birch Hill sequence ( $\mathrm{Bbps}$ ) of Robinson and others (1990) in the Fairbanks Mining District.

QUARTZITE AND LOW-GRADE SCHIST--Includes quartz-sericite schist, chlorite schist, meta-graywacke, phyllite, fine-grained silicic rocks, and greenstone. Quartzite is commonly tan, gray, or dark gray and fine or medium grained. Sulfides are locally abundant. Fine-grained hard, dense, and brittle siliceous rocks are abundant near Beaver Creek in the southwesternTanacross quadrangle. They are well to slightly foliated, but bedding is commonly apparent. Banding, which may represent bedding, is commonly isoclinally folded into recumbent folds two to ten centimeters across. Very poorly exposed. Mostly low greenschist facies metamorphism. Age is unknown but protoliths are considered to be most likely of Paleozoic age. This unit is mapped only in the Tanacross quadrangle and is included in unit $P_{2} u$ on the Tanacross 1:250,000 geologic map (Foster, 1970).

Pzcp CALCAREOUS PHYLLITE, MARBLE, AND PHYLLITE--Phyllite is gray with thin interlayers of crumbly, impure marble; black and dark-gray phyllite is quartzitic and mostly thin layered and poorly exposed; white quartz \pm calcite veins and veinlets are common; white quartz is found with tan carbonate in small lenses. Areas underlain by rock of this unit commonly have abundant, small, scattered chunks of white quartz \pm carbonate on the surface. The common presence of quartz + plagioclase + calcite + muscovite $+\mathrm{Mg}$-chlorite phyllite indicates greenschist-facies metamorphism below the stability of tremolite (chlorite zone). The age of protoliths of this rock are unknown, but geologic relations suggest that they are Paleozoic. The time of regional metamorphism also is unknown.

This unit is mapped as Pzm on both the 1:250,000 geologic map of the Big Delta quadrangle (Weber and others, 1978) and 1:250,000 geologic map of the Circle quadrangle (Foster and others, 1983). It is included in unit $c p$ of subterrane $Y_{3}$ in Foster and others (1987). It is mapped as calc-schist, Pzpbs, and calc-amphibolite, Pzbca, in the Birch Hill sequence in the Fairbanks mining district by Robinson and others (1990). 
QUARTZITIC SCHIST AND QUARTZITE--Minor pelitic schist, calc-silicate rock, mafic schist, and uncommon marble. Quartzitic schist and quartzite are generally gray, tan or greenish gray; they are fine to coarse grained and equigranular, or fine to coarse grained with rare to abundant megacrysts of quartz and less abundant feldspar which range in diameter from less than a millimeter to over a centimeter. Megacrysts are clear, white, gray, blue gray, or black and may be single strained crystals or composed of a group of strained crystals. The matrix for the large grains is generally a mosaic of strained quartz, minor feldspar and white mica and locally minor chlorite, biotite, and small garnets. Some rocks are blastomylonites which show syntectonic recrystallization in quartz. Quartzite is interlayered with minor amounts of pelitic schist (quartz + plagioclase + muscovite + chlorite, commonly with biotite \pm garnet or with chloritoid \pm garnet, and locally with carbonate). Some garnet porphyroblasts are rolled; however, garnet is absent in the northern exposures of this unit. Thin to thick-layered marble is also interlayered. Calc-silicate, light green or greenish gray, is present locally in several places in the southern Circle quadrangle. Greenschist (stippled pattern) is found in the northern Circle quadrangle; a common assemblage in this mafic schist is actinolite or actinolitic homblende + plagioclase + quartz + chlorite + epidote + sphene \pm carbonate \pm rare biotite or stilpnomelane. Locally quartz-white mica-chlorite-magnetite schist that is green in color, is interlayered with quartzite and quartz-schists including light and dark gray banded quartzite and minor, thin-layered marble. The amount of magnetite in some of these rocks is considered sufficient by Cady and Weber (1983) to have aeromagnetic expression. The rocks of unit $\mathrm{P}_{2} \mathrm{p} \mathrm{q}_{\mathrm{q}}$ are mostly wellfoliated, and four distinct deformational events are recognized. The fourth event is a broad, gentle, open folding such as has been recognized in metamorphic units in the eastern part of Plate 1 . The rocks of this unit have been regionally metamorphosed at moderate pressure, mostly under greenschist-facies conditions. Metamorphism was somewhat more intense in the southern part of the unit. Contact-metamorphic effects are superimposed upon the regional metamorphism around Tertiary plutons.

Most of this unit was included in the Precambrian Birch Creek Schist by Mertie (1937). More recently, the term Fairbanks schist unit has been applied, particularly in the Fairbanks mining district (Robinson and others, 1990). Also, a 130-m thick sequence of interlensing felsic schist, micaceous quartzite, chloritic or actinolitic schist, graphitic schist, minor metabasite, metarhyolite, calc-silicate layers, banded gray marble, and quartzite within the Fairbanks schist unit in the Fairbanks mining district has been informally described as the Cleary sequence (Bundtzen, 1982; Robinson and others, 1990). No fossils have been found in this unit, and because of poor exposure, geologic relations are difficult to determine, and many remain uncertain and controversial. U-Pb geochronology of medium- and fine-grained fractions of euhedral zircon from metarhyolite which is interpreted as a flow or tuff from the Cleary sequence, gives an age of $369 \pm 3 \mathrm{Ma}$. Coarse zircons contain a small amount of inherited material. Detrital zircons separated from metasiltstone of the Cleary sequence have isotopic systematics that indicate an Early Proterozoic provenance (about 2.1 to $2.3 \mathrm{Ga}$ ) (Aleinikoff and Nokleberg, 1989). Thus the protolith of at least some of the Fairbanks schist unit is Paleozoic (Devonian) in age. However, the interpretation that some of the unit could be Proterozoic in age cannot be completely ruled out; for instance, the origin of the Proterozoic detrital zircons is not known (Aleinikoff and Nokleberg, 1989). Because of the abundance of quartz megacrysts in the dominant quartzite component in this unit, some workers have suggested that the protolith might have been a part of the Canadian Windermere Supergroup (F.R. Weber, oral commun., 1979). 
The northwestern margin of unit PzEq is generally considered to mark the northwestern extent of the Yukon-Tanana terrane. This very poorly exposed contact separates the more highly metamorphosed rocks of the Yukon-Tanana terrane from only slightly metamorphosed rocks to the northwest. Extensive zones of cataclastic and mylonitic rocks along this contact, as well as changes in lithology, structure, and metamorphic grade, suggest to some workers that this is a significant fault contact (Laird and Foster, 1984; Foster and others, 1987, Moore and Nokleberg, 1988). However, Weber (1989; Weber and others, 1985) believes that the metamorphic grade of the rocks of the Fairbanks schist unit decreases gradually to the northeast and stratigraphically upward, that the stratigraphic succession is normal, and that no fundamental tectonic break exists.

Mertie (1937) designated this unit pe on his map, Foster and others (1983) on the 1:250,000 Circle quadrangle geologic map used the map unit designation $P_{2 p}$ Cq, and Foster and others (1987) included this unit as ps in the $Y_{1}$ subterrane. Robinson and others (1990) used P2Efs for the Fairbanks schist unit and P2Ecg, $P_{2} P_{c c e}, P_{2} E c w, P_{2} E_{c s} P_{2} E c g s, P_{2} E c i m, P_{2} E c m$, and $P_{2} E c u$ for parts of the Cleary sequence interlensed near the middle of the Fairbanks schist unit.

DOLOMITE AND MARBLE--Dolomite, gray to cream-colored and weathers tan, brown, or gray; massive, folded and lineated, but bedding is not apparent; much fractured, breaking into small fragments. Marble is gray or greenish gray and interlayered in calcareous greenish-gray and gray quartzite, greenish-gray and gray calcareous phyllite, and greenish gray calc-silicate. Unit occurs only in the westcentral Circle quadrangle as an isolated mass about $1 / 4 \mathrm{~km}^{2}$ in area. It appears to be fault bounded. The age of these rocks is unknown, but because some of the rocks resemble dolomite and marble in the Livengood quadrangle they are most likely Paleozoic or Proterozoic in age. This unit is labeled Pzpfd on the 1:250,000 geologic map of the Circle quadrangle (Foster and others, 1983).

GRIT AND QUARTZITE--Tan or gray; medium to coarse grains of quartz, minor feldspar, and polycrystalline quartz clasts are present in a matrix of carbonate, finegrained quartz, chlorite, white mica and feldspar. Carbonate may be iron-rich and iron oxides may rim the iron carbonate. Zircon and (or) tourmaline may be minor accessory minerals. Clasts are mostly angular and unoriented; locally there is granulation at grain boundaries and grains are surrounded by fine quartz, white mica, and carbonate. Quartz is generally strained. The rocks are only slightly metamorphosed and are in fault contact with more highly metamorphosed rocks. Appears similar to the grit of the Wickersham unit and is probably correlative (Weber, 1989). Weber (1989) considers the unit to be Late Proterozoic to earliest Cambrian in age, although only limited age data are available. This unit is shown at one locality on Plate 1 in the Circle quadrangle. On the 1:250,000 Circle geologic map (Foster and others, 1983) it is shown as unit Pzpfgr.

\section{Amphibolite-Facies Rocks}

MzPzmd METADIORITE--Medium to medium dark gray; fine to medium grained. Hornblende is dark green to pale brown; red-brown biotite is abundant in some outcrops. Gneissic texture; foliation locally well developed. Mapped only at one locality in the central Big Delta quadrangle. K/Ar data on homblende indicate a late Paleozoic or early Mesozoic age (Wilson and others, 1985). On the Big Delta 1:250,000 geologic map, the occurrence is shown as unit $P_{2} d$ (Weber and others, 1978). 

The most common rock type is quartz-biotite gneiss \pm garnet \pm homblende. Aluminum-silicate minerals are rane, but kyanite has been found in a few thin sections. Marble, white, light gray or pinkish-white is abundant in layers, lenses, and pods, including some large masses a square kilometer or more in area. It is medium to coarse grained, but most commonly is coarse grained. Quartzite is mostly light grey and tan and commonly breaks across grains. Augen gneiss is rare. The rocks were regionally metamorphosed at medium temperatures under fairly high pressures (Dusel-Bacon and Hansen, 1991). Locally, contact metamorphic effects, generally retrograding, are superimposed on the regional metamorphism. Foliation is fairly well developed in the gneisses and has been deformed into tight asymmetric folds that are locally isoclinal. Rarely observed small rootless folds may be an indication of an earlier period of folding. A late generation of folding has produced broad shallow open folds.

The age of the protoliths is unknown, but a few poorly preserved echinodermal fragments (Foster, 1976) suggests that they are Paleozoic in age. The major regional metamorphism is believed to have occurred in Late Triassic time on the basis of incremental heating experiments (Cushing and others, 1984; Foster and others, 1987; Hansen and others, 1991).

Unit $P_{2} b g$ is subterrane $Y_{4}$ of Foster and others (1987) and the Taylor Mountain terrane or subterrane of Dusel-Bacon and Hansen $(1992,1991)$. Some workers have considered it part of the Stikinia terrane (Nokleberg and others, 1991). Unit $\mathrm{P}_{\mathrm{zbg}}$ is found in the eastem Eagle quadrangle and northeastem Tanacross quadrangle. On the 1:250,000 geologic map of the Eagle quadrangle (Foster, 1976), it is represented by unit $P_{2 p}=b$. On the 1:250,000 geologic map of the Tanacross quadrangle (Foster, 1970), it is unit $P_{2 u}$.

GNEISS AND SCHIST--Includes quartz-biotite \pm garnet gneiss, augen gneiss and other orthogneiss, pelitic gneiss, quartzite, amphibolite, schistose gneiss, and quartz-mica schist. Calcareous rocks are very rare in the eastem part of the map area; in the western part coarsely crystalline marble is present rarely as pods in pelitic gneiss and interlayered in some schists. Because augen gneiss is a widely distributed and characteristic rock type in the area of this unit, the large bodies of augen gneiss in the Big Delta quadrangle that are believed to be intrusive into other rocks of unit $P_{z g n}$ before regional metamorphism are mapped as unit $P_{z g n a}$ However, small exposures of augen gneiss and augen gneiss interlayered with other gneisses, amphibolite, quartzite, and schist are indicated by squares within unit Pzgn. Sillimanite gneiss, although considered a part of this unit, is such a major rock type in the Big Delta quadrangle that large areas are shown and described separately ( $\left.P_{2} g n s\right)$. North of the Salcha River, pelitic gneiss is interlayered with quartzitic schist, quartzite, amphibole schist, quartzofeldspathic schist, and a little marble. These large areas of unit $\mathrm{P}_{\mathbf{2}}$ gn that are more schistose and (or) quartzitic are shown by dashes and labeled as unit $P_{z} g n s q$. Thus, all units with the prefix $P_{2} g n$ ( $P_{z} g n a, P_{z} g n s$, and $P_{z g n s q}$ ) are parts of unit $P_{z g n}$ that are differentated by lithology. Their descriptions are indented in the text and in "Definition of Map Units" on Plate 1 to show this relationship.

The rocks of unit $\mathrm{Pzgn}$ are mostly of the middle amphibolite facies but range in grade from epidote-amphibolite facies to the second-sillimanite isograd. In the eastern part of the map area, rocks of this unit were metamorphosed under highpressure conditions (Dusel-Bacon and Hansen, 1991). In the northern part of the sillimanite gneiss area, they have been metamorphosed at intermediate to fairly low 
pressure (Sisson and others, 1990). Elsewhere, they were probably metamorphosed mostly at intermediate to fairly high pressures. The rocks of unit Pzgn are well foliated, and foliation is folded at least once. Gneissic banding is well-developed in places. Locally foliation is plastically folded. Most of the rocks show varying degrees of mylonitization and post-mylonitization recrystallization.

Protolith ages of unit $\mathrm{Z}_{\mathrm{zgn}}$ are poorly known. The augen gneiss has an intrusive age of Mississippian, $341 \pm 3 \mathrm{Ma}$ (Aleinikoff and others, 1986). The paragneisses and schists, and quartzites of unit $P_{z g n}$ are interpreted as wall rocks of the orthoaugen gneisses and are thus considered Mississippian or older. An early Paleozoic age seems likely for most of them, but a Proterozoic age for at least some cannot be ruled out. Time of metamorphism and deformation of unit $P_{2}$ n is not known but isotopic age determinations are interpreted by some workers as indicating that the major regional-metamorphism is Cretaceous in age (Nokleberg and others, 1989).

The rocks of unit Pzgn were included in the Precambrian Birch Creek Schist by early workers (Mertie, 1937). Pzgn is included in the $Y_{1}$ subterrane of Foster and others (1987) and in the Lake George subterrane of Nokleberg and others (1989). Unit Pzgn combines several units that are shown separately on the 1:250,000 geologic map of the Big Delta quadrangle (Weber and others, 1978). Unit Pzgn is mostly Big Delta map unit $P_{z p}$ g. On the 1:250,000 geologic map of the Eagle quadrangle (Foster), 1976, unit $P_{2 g}$ is represented by unit $P_{2 p} C_{g}$ (partly orthogneiss), and in a few localities by unit $P_{2 p} \mathrm{Cb}$. On the 1:250,000 geologic map of the Tanacross quadrangle Alaska (Foster, 1970) unit Pzgn is represented by unit Pzpeb.

AUGEN GNEISS--Gneiss with a blastoporphyritic texture and granitic composition consisting of large (1 to $9 \mathrm{~cm}$ in longest direction) augen of potassium feldspar in a fine to medium-grained matrix of biotite + muscovite + quartz + plagioclase \pm potassium feldspar (Dusel-Bacon and Aleinikoff, 1985). Augen gneiss is surrounded by, and commonly contains inliers of, quartz-mica schist and amphibolite (unit Pzgn). Concordant layers of quartzofeldspathic gneiss, generally several centimeters to 1 or $2 \mathrm{~m}$ thick, are locally intercalated. Augen gneiss generally has well-developed gneissic banding which is concordant with that of the rocks of unit Pzgn. Foliation is commonly subhorizontal, but may be highly deformed locally. Most of the rocks show varying degrees of mylonization and recrystallization. A lineation formed by intersection of the axes of small tight folds with foliations is present locally in augen gneiss in the Big Delta quadrangle and is well-developed in the northeastern Tanacross quadrangle. The augen gneiss is believed to have developed from granitoids intrusive into the rocks of unit Pzgn in Mississippian time (about $340 \mathrm{Ma}$ ) and to have been metamorphosed under amphibolite-facies conditions along with the country rocks (Dusel-Bacon and Aleinikoff, 1985).

The rocks of unit Pzgna were mapped in the Precambrian Birch Creek Schist by Mertie (1937), although he considered them to be part of the Pelly Gneiss, a formation mapped in the Yukon Territory (McConnell, 1905). Unit Pzgna is included in the $Y_{1}$ subterrane of Foster and others (1987) and in the Lake George subterrane of Nokleberg and others (1989). On the 1:250,000 scale geologic map of the Big Delta quadrangle (Weber and others, 1978) and on the 1:250,000 scale geologic map of the Eagle quadrangle (Foster 1976), unit Pzgna is represented by unit $P_{z p} C_{a}$. On the 1:250,000 scale geologic map of 
the Tanacross quadrangle (Foster, 1970), unit $P_{2} g n$ is included in unit $P_{2 p}=b$. On the 1:250,000 scale geologic map of the Circle quadrangle (Foster and others, 83), unit Pzgna is present as a few small localities of augen gneiss, indicated as unit $\mathrm{Da}$.

SILLIMANITE GNEISS--Mostly sillimanite-bearing gneiss of comparatively uniform composition and texture, but locally may include minor amphibolite, quartz-mica schist, and quartzite, and thin calcareous schist layers and nodules or lenses of marble. Felsic dikes, some pegmatitic, also are present. Foliation is generally moderately to poorly developed, and throughout much of the unit is nearly horizontal because of recumbent isoclinal folding on both a mesoscopic and macroscopic scale. In the west-central Big Delta quadrangle, sillimanite gneiss of this unit crops out over approximately $600 \mathrm{~km}^{2}$ in a topographically high area that is interpreted as a gneiss dome. The gneiss dome consists mostly of quartz-orthoclase-plagioclase-biotite-sillimanite \pm muscovite gneiss; the high grade core of the dome contains the assemblage biotite + sillimanite + quartz + cordierite + orthoclase + plagioclase + garnet \pm muscovite (Dusel-Bacon and Foster, 1983). Sillimanite is rarely coarse enough to be seen with a hand lens. Biotite-rich layers and clots of biotite are present locally, and swirly banding may be evident in some biotite-rich layers. Migmatitic streaking was observed in a few areas. Unfoliated andalusitebearing granitic-appearing rocks are locally present in the central part of the gneiss dome (Dusel-Bacon and Foster, 1983). To the north of the gneiss dome muscovite gradually increases and potassium feldspar decreases. Foliation is plastically folded in the gneiss dome.

The age of the protoliths of this unit is not known, but is believed to be Paleozoic on the basis of their association with other rocks of unit $\mathrm{Zzgn}$. The rocks were initially regionally metamorphosed in the amphibolite facies at intermediate pressures of about $5 \mathrm{~kb}$ (Sisson and others, 1990). Pressure determinations were made on the basis of the presence of staurolite-kyanitesillimanite schist and garnet-bearing amphibolite on the northwest edge of the dome, garnet-cordierite geobarometry in the core of the dome, and geobarometry on plagioclase inclusions in garnet. However, there is also evidence from geothermobarometry, the presence of andalusite-bearing quartz veins, and the growth of texturally late andalusite in pelitic schist that later lowpressure metamorphic conditions also affected the rocks of the dome (Sisson and others, 1990). Time or times of metamorphism remain uncertain, but were probably during the Mesozoic.

The rocks of unit $\mathrm{P}_{\mathbf{2}}$ gns were included in the Precambrian Birch Creek Schist by Mertie (1937). Unit $\mathbf{Z}_{2}$ gns is included in the $Y_{1}$ subterrane of Foster and others (1987) and in the Lake George subterrane of Nokleberg and others (1989). Unit $\mathrm{P}_{2 \mathrm{gn}}$ is unit $\mathrm{Zzg}$ on the 1:250,000 geologic map of the Big Delta quadrangle (Weber and others, 1978).

Pzgnsq

SCHIST AND QUARTZITE--Quartz-mica schist, generally high in biotite, commonly garnetiferous, and locally feldspathic. Minor interlayered marble is found north of the Salcha River, and some interlayered amphibole-bearing schist is present. A typical mineralogy in the area north of the Salcha River is quartz+oligoclase or andesine+potassium feldspar + muscovite + biotite + garnet + staurolite, and zircon, apatite, sphene, or rutile, and opaque minerals are accessories. Kyanite, andalusite, and sillimanite are present in several combinations in the more pelitic rocks (Dusel-Bacon and Foster, 1983). Metamorphic grade ranges from epidote-amphibolite to middle amphibolite 
facies; locally the rocks are retrograded. Age of the protoliths is unknown, but geologic relations indicate that they are probably Paleozoic, although a Proterozoic age for some of these rocks cannot be completely ruled out at present. The schist and quartzite of unit Pzgnsq more or less surrounds the gneiss dome of unit Pzgns (except on the south) and are in contact along a low-angle ductile shear zone (Pavlis and others, 1988) with greenschist facies rocks of unit Pzms. Pavlis and others (1988) postulate that mid-Cretaceous extension resulted in the juxtaposition of the lower grade rocks of unit Pzms on the higher grade rocks (footwall) of unit Pzgnsq.

These rocks are shown as unit $P_{2 S}$ and $P_{2 p} C_{S}$ on the 1:250,000 geologic map of the Big Delta quadrangle (Weber and others, 1978).

ULTRAMAFIC ROCKS--Light green, greenish gray, or black, and less commonly, brown or yellow green; dark yellow brown on weathered surfaces. Compressed bastite in a fine-grained groundmass indicates that the original rock was mostly peridotite (harzburgite) which has been regionally metamorphosed to amphibole, chlorite, and magnetite with or without serpentine, brucite, talc, magnesite, and anthophyllite. Serpentine is mostly antigorite with brucite and magnetite commonly associated. Intense recrystallization has formed elongate oriented olivine with pods of granular magnetite as long as $5 \mathrm{~cm}$. Foliation is well-developed and the ultramafic rocks are infolded with or structurally placed against amphibolite facies gneiss and schist. Many exposures are too small to be shown on this map. Some of these rocks crop out in a discontinuous irregular belt of small exposures across the southern Big Delta quadrangle and into the southwestern Eagle quadrangle. The age of these ultramafic rocks is not known, but because they are interlayered and infolded with rocks of unit Pzgn of probable Paleozoic age they are considered most likely to be of Paleozoic age. They were regionally metamorphosed at the same time as $P$ zgn so were probably metamorphosed in Mesozoic time, although late Paleozoic is also a possible time of metamorphism.

These ultramafic rocks were included in the $Y_{1}$ subterrane, unit ag, in Foster and others (1987). On the Eagle 1:250,000 geologic map (Foster, 1976) they were included in unit MzPzsp. In the Big Delta quadrangle these ultramafic rocks are also mapped as unit Pzu.

ECLOGITE AND ASSOCIATED ROCK-Includes amphibolite, impure marble, pelitic schist, and mafic glaucophane-bearing schist. Eclogitic rocks (shown on the map in solid black), generally green in color, are present in very limited exposure associated with schist and impure marble in the southeastern Livengood and southwestern Circle quadrangles. Eclogitic rocks from the Livengood area consist of several combinations of garnet, omphacitic clinopyroxene, amphibole, calcite, phengitic mica, quartz, albite, epidote, sphene, and rutile probably derived from marls and graywackes (Swainbank, in Hall and others, 1984). Assemblages containing glaucophane and kyanite-staurolite-chloritoid have also been found. In the Circle quadrangle eclogite appears to be from a mafic layer within quartz and white mica + garnet (somewhat retrograded to chlorite) schist and quartzite, the protolith of which may have been a dike. The mafic layers consist of garnet, omphacite, quartz, clinoamphibole (barroisite to alumino-barroisite), clinozoisite, white mica, rutile, and sulfide (trace). (Laird and others, 1984). Eclogites of both the Livengood and Circle quadrangles fall within Group $\mathrm{C}$ of Coleman and others (1965) and are similar to eclogites from alpine-type orogenic terranes.

Crystallization temperatures were estimated to be around $600^{\circ} \pm 50^{\circ} \mathrm{C}$ and pressures around $13-15 \mathrm{~kb}$ (Foster and others, 1986). The eclogites are included in a unit 
generally referred to as the Chatanika terrane, considered to be the upper plate of a folded thrust (Hall and others, 1984).

Radiometric age determinations, some of which are still in progress, suggest that protoliths may be of Paleozoic age and that metamorphism may have been in the Cretaceous, although earlier metamorphism(s) cannot be ruled out. These rocks are in unit ec of subterrane $Y_{1}$ in Foster and others (1987) and are in the Chatanika subterrane of Nokleberg and others (1989). On the Circle quadrangle 1:250,000 geologic map (Foster and others, 1987) they are included in units Pe and PzpCms.

\section{PzPs}

SCHIST, QUARTZITE, GNEISS, BLASTOMYLONITE, MARBLE, AND AMPHIBOLE--Pelitic schist, medium to coarse grained, with interlayers of quartzitic schist, quartzite, and marble, is the dominant rock type. Other interlayered rocks include augen gneiss, calc-silicate, amphibolite, and ultramafic rocks. Pelitic gneiss, orthogneiss, and blastomylonite also are present. The largest areas of gneiss are shown on the map by the symbol . Major areas of blastomylonite and other cataclastic rocks are indicated by a triangle symbol. Rocks included in this unit in the Eagle quadrangle which are indicated by vertical dashes are mostly hornfelsed and retrograded gray quartzitic, graphitic, and calcareous schists of uncertain affinities.

Regional metamorphism of the unit ranges from amphibolite facies to epidoteamphibolite facies (sillimanite + potassium feldspar to garnet grade in pelitic schist and gneiss). The highest grade rocks occur in the southeastern part of the Circle and northeastern part of the Big Delta quadrangles. A characteristic mineral assemblage in the highest grade rocks is quartz + plagioclase + white mica + biotite + sillimanite \pm potassium feldspar \pm garnet. Other pelitic assemblages in the higher grade part of the unit are biotite + garnet + staurolite \pm kyanite; biotite + garnet + kyanite; biotite + kyanite + sillimanite; all with quartz + white mica + plagioclase. Metamorphic grade decreases northward and westward and is also lower in the northern Eagle quadrangle. A common pelitic assemblage to the north and west of the highest grade rocks is quartz + white mica + biotite + garnet + chlorite + plagioclase. Mafic schist is homblende + plagioclase + quartz + epidote \pm chlorite + biotite. Augen gneiss, mostly biotite felsic gneiss containing augen-shaped potassium feldspar crystals, is present in minor amounts in the southeastern part of the Circle quadrangle. Augen are generally composed of two or more potassium feldspar crystals. Variations in the size of augen and in the relative proportions of mineral constituents, and field relations suggest that the augen gneisses do not all have the same origin and that the protoliths probably include both igneous and sedimentary rocks. Many are blastomylonites. Some augen gneiss occurrences may be folded metamorphosed dikes and sills (F.R. Weber, oral commun., 1979 in Foster and others, 1987). Most of the larger areas of augen gneiss may be erosional remnants of unit Rgna and are labeled Pzgna on the map. In the southeastern Circle quadrangle graybrown weathering quartzite with minor interlayers of pelitic and quartzitic schists is found as platy coarse rubble which "clinks" when struck with a hammer. The quartzite consists primarily of quartz with biotite, white mica, and plagioclase. Locally it contains garnet or potassium feldspar. Small scattered exposures of metamorphosed ultramafic rocks within this unit (too small to be shown on this map) consist mainly of actinolite, chlorite, serpentine, magnetite, chlorite, talc, and magnesite. Relict olivine, orthopyroxene, and clinopyroxene are found locally. Many of the ultramafic rocks are found at or near the edge of thrust plates which compose this unit.

All of the rocks of this unit are polydeformed and cataclastic textures are common throughout the unit. In the northwestern Eagle quadrangle along the Charley River, 
classic mylonitic textures are found in gneiss and schist which are tentatively mapped in this unit. Polymetamorphism of regional extent has not been definitely identified in this unit, but contact metamorphism is indicated around some of the Tertiary plutons where pseudomorphs of white mica after staurolite and kyanite occur. This unit may include protoliths of both Precambrian and Paleozoic age. A uranium-lead age on zircon from an orthogneiss in the northeastern Big Delta quadrangle was $671 \pm 34 \mathrm{Ma}$ (J.N. Aleinikoff, personal commun., 1987). A concordant uranium- lead age on monazite from the orthogneiss of $115 \mathrm{Ma}$ (J.N. Aleinikoff, personal commun., 1987) indicates that an Early Cretaceous thermal event affected these rocks and may represent the time of major regional metamorphism.

This unit (Pzs) is unit ps in subterrane $Y_{2}$ in Foster and others (1987). It includes units Pzpeg and Pzpfsq on the Big Delta 1:250,000 geologic map (Weber and others, 1978) and unit Pzpes on the Circle 1:250,000 geologic map (Foster and others, 1983). This unit may also extend into the northern Eagle quadrangle, but because its occurrence there is uncertain the unit is queried in those areas on Plate 1. On the Eagle 1:250,000 geologic map (Foster, 1976) the queried part of this unit was included in units $P_{2 p}$ Ob or Pzb. 


\section{REFERENCES CITED}

Aleinikoff, J.N., Dusel-Bacon, Cynthia, and Foster, H.L., 1986, Geochronology of augen gneiss and related rocks, Yukon-Tanana terrane, east-central Alaska: Geological Society of America Bulletin, v. 97, p. 626-637.

Aleinikoff, J.N., Dusel-Bacon, Cynthia, Foster, H.L., and Nokleberg, W.J., 1987, Lead isotopic fingerprinting of tectono-stratigraphic terranes, east-central Alaska: Canadian Journal of Earth Sciences, v. 24, p. 2089-2098.

Aleinikoff, J.N. and Nokleberg, W.J., 1989, Age of deposition and provenance of the Cleary sequence of the Fairbanks schist unit, Yukon-Tanana terrane east-central Alaska, in Dover, J.H. and Galloway, J.P., eds., Geologic studies in Alaska by the U.S. Geological Survey, 1988: U.S. Geological Survey Bulletin 1903, p. 75-83.

Bacon, C.R., Foster, H.L., and Smith, J.G., 1990, Rhyolitic calderas of the Yukon-Tanana terrane, east central Alaska: Journal of Geophysical Research, v. 93, no. B13, p. 21451-21461.

Brabb, E.E., and Churkin, Michael, Jr., 1969, Geologic map of the Charley River quadrangle, eastcentral Alaska: U.S. Geological Survey Miscellaneous Geologic Investigations Map I-573, scale $1: 250,000$.

Brown, E.H., and Forbes, R.B., 1986, Phase petrology of eclogitic rocks in the Fairbanks district, Alaska, in Evans, B.W., and Brown, E.H., eds., Blueschists and eclogites: Geological Society of America Memoir 164, p. 155-167.

Bundtzen, T.K., 1982, Bedrock geology of the Fairbanks mining district, western sector: Alaska Division of Geological and Geophysical Surveys Open-File Report, No. 155, 2 pls.

Cady, J.W., and Weber, F.R., 1983, Aeromagnetic map and interpretation of magnetic and gravity data, Circle quadrangle, Alaska: U.S. Geological Survey Open-File Report 83-170C, 31 p.

Chapman, R.M., Weber, F.R., and Taber, Bond, 1971, Preliminary geologic map of the Livengood quadrangle, Alaska: U.S. Geological Survey Open-File Report 71-66, scale 1:250,000.

Churkin, Michael Jr., Foster, H.L., Chapman, R.M., and Weber, F.R., 1982, Terranes and suture zones in east-central Alaska: Journal of Geophysical Research, v. 87, no. 135, p. 3718-3730.

Coleman, R.G., Lee, D.E., Beatty, L.B. and Brannock, W.W., 1965, Eclogites and eclogites: Their differences and similarities: Geological Society of America Bulletin, v. 76, no. 5, p. 483508.

Cushing, G.W., Foster, H.L., Harrison, T.M., and Laird, Jo, 1984, Possible Mesozoic accretion in the eastern Yukon-Tanana Upland, Alaska: Geological Society of America, 97th Annual Meeting, Abstracts with Programs, p. 481.

DuBois, G.D., Wilson, F.H., and Shew, Nora, 1986, Map and tables showing potassium-argon age determinations and selected major-element chemical analysis from the Circle quadrangle, Alaska: U.S. Geological Survey Open-File Report 86-392, scale 1:250,000.

Dusel-Bacon, Cynthia, and Foster, H.L., 1983, A sillimanite gneiss dome in the Yukon crystalline terrane, east-central Alaska: petrography and garnet-biotite geothermometry: U.S. Geological Survey Professional Paper 1170-E, 24 p. 
Dusel-Bacon, Cynthia, and Aleinikoff, J.N., 1985, Petrology and tectonic significance of augen gneiss from a belt of Mississippian granitoids in the Yukon-Tanana terrane, east-central Alaska: Geological Society of America Bulletin, v. 96, p. 411-425.

Dusel-Bacon, Cynthia, and Hansen, V.L., 1991, High-pressure, medium-temperature early Mesozoic metamorphism and deformation within the Yukon-Tanana composite terrane, eastern Alaska: 1991 Abstracts with Programs, Cordilleran Section, The Geological Society of America, v. 23, no. 2 , p. 20.

Dusel-Bacon, Cynthia, and Hansen, V.L., 1992, High-P, moderate-T metamorphism and ductile deformation during Early Mesozoic subduction and accretion, east-central Alaska [abs.]: Geological Society of America Abstracts With Programs, v. 24, no. 5, p. 21.

Forbes, R.B., and Weber, F.R., 1982, Bedrock geologic map of the Fairbanks mining district, Alaska: State of Alaska, Division of Geological and Geophysical Surveys, Open-File Report AOF-170.

Foster, H.L., 1970, Reconnaissance geologic map of the Tanacross quadrangle, Alaska: U.S. Geological Survey Miscellaneous Geologic Investigations Map I-593, scale 1:250,000.

Foster, H.L., 1976, Geologic map of the Eagle quadrangle, Alaska: U.S. Geological Survey Miscellaneous Geologic Investigations Series Map I-922, scale 1:250,000.

Foster, H.L., 1981, A minimum age for Prindle Volcano, Yukon-Tanana Upland, in Albert, N.R.D., and Hudson, Travis, eds., The United States Geological Survey in Alaska: Accomplishments during 1979: U.S. Geological Survey Circular 823-B, p. B37-B38.

Foster, H.L. and Cushing, G.W., 1985, Tertiary (?) folding in the Tanacross quadrangle, in Bartsch-Winkler, Susan, and Reed, K.M., eds., The United States Geological Survey in Alaska: Accomplishments during 1983: U.S. Geological Survey Circular 945, p. 38-40.

Foster, H.L., Cushing, G.W., and Keith, T.E.C., 1985, Early Mesozoic tectonic history of the boundary area, east-central Alaska: Geophysical Research Letters, v. 12, no. 9, p. 553-556.

Foster, H.L., Forbes, R.B., and Ragan, D.M., 1966. Granulite and peridotite inclusions from Prindle Volcano, Yukon-Tanana Upland, Alaska: U.S. Geological Survey Professional Paper 550-B, p. B115-B119.

Foster, H.L., and Igarashi, Yaeko, 1990, Fossil pollen from nonmarine sedimentary rocks of the eastern Yukon-Tanana region, east-central Alaska, in Dover, J.H., and Galloway, J.P., eds., Geologic Studies in Alaska by the U.S. Geological Survey, 1989: U.S. Geological Survey Bulletin 1946, p. 11-20.

Foster, H.L., and Keith, T.E.C., 1974, Ultramafic rocks of the Eagle quadrangle, east-central Alaska: Journal of Research, U.S. Geological Survey, v. 2, no. 6, p. 657-669.

Foster, H.L., and Keith, T.E.C., 1987, Preliminary geology, including the Tintina fault system of part of the southwestern Charley River quadrangle, Alaska, in Hamilton, T.D., and Galloway, J.P., eds., Geological Studies in Alaska by the U.S. Geological Survey during 1986, U.S. Geological Survey Circular 998, p. 59-61.

Foster, H.L., Keith, T.E.C., and Menzie, W.D., 1987, Geology of east-central Alaska: U.S. Geological Survey Open-File Report 87-188, 59 p. 
Foster, H.L., Laird, Jo, Keith, T.E.C., Cushing, G.W., and Menzie, W.D., 1983, Preliminary geologic map of the Circle quadrangle, Alaska: U.S. Geological Survey Open-File Report 83$170 \mathrm{~A}, 29$ p., scale 1:250,000.

Gilbert, W.G., and Bundtzen, T.K., 1979, Mid-Paleozoic tectonics, volcanism, and mineralization in north-central Alaska Range: Geological Society of America, Symposium Proceedings 1977, p. F1-F22.

Green, L.H., 1972, Geology of Nash Creek, Larsen Creek, and Dawson map-areas, Yukon Territory: Geological Survey of Canada Memoir 364, p. 1-157.

Hall, M.H., Smith, T.E., and Weber, F.R., 1984, Geologic guide to the Fairbanks-Livengood area, east-central Alaska, 30 p.

Hansen, V.L., 1990, Yukon-Tanana terrane: a partial acquittal: Geology, v. 18, p. 365-369.

Hansen, V.L., Heizler, M.T., and Harrison, T.M., 1991, Mesozoic thermal evolution of the YukonTanana composite terrane: New evidence from ${ }^{40} \mathrm{Ar} / 39 \mathrm{Ar}$ data: Tectonics, v. 10 , p. 51-76.

Jones, D.L., Silberling, N.J., Coney, P.J., and Plafker, George, 1984, Lithotectonic terrane map of Alaska (west of the 141st Meridian), Part A, in Silberling, N.J., and Jones, D.L., eds., Lithotectonic terrane maps of the North American Cordillera: U.S. Geological Survey Open-File Report 84-523, p. A1-A12.

Keith, T.E.C., Foster, H.L., Foster, R.L., Post, E.V. and Lehmbeck, W.L., 1981, Geology of an alpine-type peridotite in the Mt. Sorenson area, east-central Alaska, in Shorter contributions to general geology: U.S. Geological Survey Professional Paper 1170-A, p. 1A-9A.

Laird, Jo, Biggs, D.L., and Foster, H.L., 1984, A terrane boundary of the southeastern Circle quadrangle, Alaska? Evidence from petrologic data [abs.]: EOS (American Geophysical Union Transactions), v. 65, no. 16, p. 291.

Laird, Jo, and Foster, H.L., 1984, Description of a mylonitic foliated quartzite unit and feldspathic quartz wacke (grit) unit in the Circle quadrangle Alaska, Reed, K.M. and Bartsch-Winkler, Susan, eds., in Accomplishments during 1982: U.S. Geological Survey Circular 939, p. 29-33.

Laird, Jo, Foster, H.L., and Weber, F.R., 1984, Amphibolite eclogite in the Circle quadrangle, Yukon-Tanana Upland, Alaska: in Coonrad, W.L., and Elliott, R.W., eds., The United States Geological Survey in Alaska: Accomplishments during 1981: U.S. Geological Survey Circular 868, p.57-60.

McConnell, R.G., 1905, Report on the Klondike gold fields: Geological Survey of Canada, Annual Report (new series), v. 14, pt. B, 71 p.

Mertie, J.B., Jr., 1937, The Yukon-Tanana region, Alaska: U.S. Geological Survey Bulletin 872, $276 \mathrm{p}$.

Metcalfe, Paul, and Clark, G.S., 1983, Rb-Sr whole-rock age of the Klondike Schist, Yukon Territory: Canadian Journal of Earth Sciences, v. 20, no. 5, p. 886-891.

Moore, T.E., and Nokleberg, W.J., 1988, Stratigraphy, sedimentology, and structure of the Wickersham terrane in the Cache Mountain area, east-central Alaska: in Galloway, J.P., and Hamilton, T.D., eds., Geologic studies in Alaska by the U.S. Geological Survey during 1987, U.S. Geological Survey Circular 1016, p. 75-80. 
Mortensen, J.K., and Sullivan, R.W., 1991, U-Pb zircon ages, Nd isotopic compositions and tectonic significance of Middle and Late Paleozoic magmatism in the Yukon-Tanana terrane, western Yukon Territory, Canada [abs.]: Geological Society of America Abstracts with Programs, v. 23, no. 5, p. A434.

Mullins, W.J., McQuat, J.F., and Rogers, R.K., 1984, The Alaska asbestos project, Part 1, project review: Industrial Minerals, no. 199, p. 41.

Nokleberg, W.J., Foster, H.L., and Aleinikoff, J.N., 1989, Geology of the northern Copper River Basin, eastern Alaska Range, and southern Yukon-Tanana Upland in Schmidt, R.A.M., Nokleberg, W.J., and Page, R.A., Alaska geological and geophysical transect, Field Trip Guidebook T104, 28th International Geological Congress, American Geophysical Union, Washington, D.C., p. T104:34-T104:63.

Nokleberg, W. J., Foster, H. L., Lanphere, M. A., Aleinikoff, J. N., and Pavlis, T. L., 1991, Structure and tectonics of the Yukon-Tanana, Wickersham, Seventymile, and Stikinia Terranes along the Trans-Alaskan Crustal Transect (TACT), east-central Alaska [abs.]: Geological Society of America Abstracts with Programs, v. 23, no. 2, p. 84.

Pavlis, T.L., Sisson, V.B., Nokleberg, W.J., Plafker, George, and Foster, H.L., 1988, Evidence for Cretaceous crustal extension in the Yukon crystalline terrane, east-central Alaska, EOS, Trans American Geophysical Union, v. 69, no. 44, p. 1453.

Robinson, M.S., Smith, T.E., and Meltz, P.A., 1990, Bedrock geology of the Fairbanks Mining District, Professional Report 106, Division of Geological and Geophysical Surveys, State of Alaska, 2 sheets.

Schmidt, R.A.M., Nokleberg, W.J., and Page, R.A., 1989, Alaskan Geological and Geophysical transect, Field Trip Guidebook T104, 28th International Geological Congress, American Geophysical Union, Washington, D.C., 131 p.

Sisson, V.B, Pavlis, T.L., and Dusel-Bacon, Cynthia, 1990, Metamorphic constraints on Cretaceous crustal extension in the Yukon Crystalline terrane, east-central Alaska [abs.]: Geological Association of Canada, Mineralogical Association of Canada Annual Meeting, Programs with abstracts, v. 15, p. A-122.

Southworth, D.O., 1984, Geologic and geochemical investigations of the "nail" allochthon, eastcentral Alaska: U.S. Bureau of Mines Open-File Report 126-84, 19 p.

Tempelman-Kluit, D.J., 1976, The Yukon crystalline terrane: Enigma in the Canadian Cordillera; Geological Society of America Bulletin, v. 87, p. 1343-1357.

Tempelman-Kluit, D.J., 1979, Transported cataclasite, ophiolite, and granodiorite in Yukon: Evidence of arc-continent collision: Geological Survey of Canada, Paper 79-A, 27 p.

Tempelman-Kluit, D.J., and Wanless, R.K., 1980, Zircon ages for the Pelly Gneiss and Klotassin granodiorite in western Yukon: Canadian Journal of Earth Sciences, v. 17, no. 3, p.297-306.

Wahrhaftig, Clyde, 1965, Physiographic divisions of Alaska: U.S. Geological Survey Professional Paper 482, 52 p.

Weber, F.R., 1989, Geology between Fairbanks and the Yukon River, east-central Alaska, in Schmidt, R.A.M., Nokleberg, W.J., and Page, R.A., Alaska geological and geophysical transect Field Trip Guidebook T104, 28th International Geological Congress, American Geophysical Union, Washington, D.C., p. T104:84-T104:95. 
Weber, F.R., and Foster, H.L., 1982, Tertiary (?) conglomerate and quaternary faulting in the Circle quadrangle, Alaska: in Coonrad, W.L., ed., the United States Geological Survey in Alaska: Accomplishments during 1980, U.S. Geological Survey Circular 844, p. 58-61.

Weber, F.R., Foster, H.L., Keith, T.E.C., and Dusel-Bacon, Cynthia, 1978, Preliminary geologic map of the Big Delta quadrangle: U.S. Geological Survey Open-File Report 78-529-A, scale $1: 250,000$.

Weber, F.R., Smith, T.E., Hall, M.H., and Forbes, R.B., 1985, Geologic Guide to the FairbanksLivengood area, east-central Alaska: Alaska Geological Society, Anchorage, AK, 44 p.

Wheeler, J.O., and McFeely, P., 1987, Tectonic assemblage map of the Canadian Cordillera and adjacent parts of the United States of America: Geological Survey of Canada Open-File Report 1565,2 sheets.

Wilson, F.H., Smith, J.G., and Shew, N., 1985, Review of radiometric data from the Yukon Crystalline Terrane, Alaska, and Yukon Territory: Canadian Journal of Earth Sciences, v. 22, no. 4, p. 525-537. 